Ál-fâhim: Jurnal Manajemen Pendidikan Islam

Volume 3 No. 2. March-September 2021

ISSN: 2656-226X; E-ISSN: 2656-6036

DOI: $10.0118 /$ alfahim.v3i2.183

\title{
Pengembangan Manajemen Sumber Daya Manusia di Lembaga Pendidikan Islam
}

\author{
Ramdanil Mubarok
}

Sekolah Tinggi Agama Islam (STAI) Sangatta

danil.education@gmail.com

\begin{abstract}
Qualified human resources will lead educational institutions to achieve their goals easily. This paper was written to know the concept of developing human resource management is, and the process of developing human resource management in Islamic educational institutions is. The author uses a qualitative approach to the type of literature (library research). The stages of the research that the author did were collecting research materials, reading literature, making small notes, processing the readings into research data. After analyzing the results obtained, among others: The concept of human resource management development is an activity of planning, coordinating, implementing, and evaluating. The process of developing human resource management includes education, training, and self-development. In more detail the process of developing human resources through, first: by conducting a needs diagnosis, second: conducting problem design, program design, participation design, educational calendar design, individual needs design, a group needs design, time design, procedure, and evaluation, third: the implementation process, and finally carry out the evaluation.
\end{abstract}

Keywords: Management, Human Resources, Educational Institutions

Abstrak: Sumber daya manusia yang mumpuni akan mengantarkan lembaga pendidikan mencapai tujuan dengan mudah. Paper ini ditulis dengan tujuan untuk mengetahui konsep pengembangan manajemen sumber daya manusia, dan proses pengembangan manajemen sumber daya manusia di lembaga pendidikan Islam. Penulis menggunakan pendekatan kualitatif dengan jenis kepustakaan (library research). Tahapan penelitian yang penulis lakukan adalah mengumpulkan bahan penelitian, membaca literatur, membuat catatan kecil, mengolah hasil bacaan menjadi data penelitian. Setelah melakukan analisa didapatkan hasil antara lain: Konsep pengembangan manajemen sumber daya manusia merupakan aktivitas perencanaan, pengkoordinasian, pelaksanaan, dan pengevaluasian. Adapun proses pengembangan manajemen sumber daya manusia diantaranya: pendidikan, pelatihan, dan pengembangan diri. 
Lebih rinci lagi proses pengembangan sumber daya manusia melalui, pertama: dengan melakukan diagnosa kebutuhan, kedua: melakukan desain masalah, desain program, desain partisipasi, desain kalender pendidikan, desain kebutuhan individu, desain kebutuhan kelompok, desain waktu, prosedur, dan evaluasi, ketiga: proses pelaksanaan, dan terakhir melaksanakan evaluasi.

Kata Kunci: Manajemen, Sumber Daya Manusia, Lembaga Pendidikan

\section{Pendahuluan}

Pengelolaan sumber daya manusia merupakan hal pokok sebagai upaya strategis dalam memaksimalkan pengelolaan lembaga pendidikan ${ }^{1}$. Setiap lembaga pendidikan membutuhkan manajemen, baik itu manajemen kurikulum, manajemen sarana dan prasarana, manajemen pembelajaran, manajemen pembiayaan, dan yang lebih spesifik lagi yaitu manajemen sumber daya manusia ${ }^{2}$. Pengelolaan sumber daya manusia masa kini yang serba canggih dan terbuka dengan kemajuan iptek merupakan sebuah tantangan lembaga pendidikan ${ }^{3}$. Syarat mutlak bagi lembaga pendidikan apabila ingin survive di era globalisasi maka tidak ada pilihan lain yaitu mengembangkan kompetensi sumber daya manusia.

Pengembangan manajemen sumber daya manusia memang bukanlah perkara mudah untuk dilaksanakan karena pada dasarnya manusia memiliki tingkat kemampuan yang berbeda. Oleh karena itu dibutuhkan keterlibatan pihak terkait guna terlaksananya pengembangan sumber daya manusia. Untuk dapat ikut serta dalam mencapai visi, misi, dan tujuan lembaga pendidikan sumber daya manusia harus dikelola dan dikembangkan secara berkelanjutan.

Tujuan pokok dalam pengembangan manajemen sumber daya manusia yaitu: 1) untuk memperbaiki kinerja, 2) untuk mengupgrade kompetensi, 3) untuk mengupgrade kemampuan TIK, 4) untuk memecahkan permasalahan, 5) untuk promosi ${ }^{4}$. Tujuan tersebut menjadi acuan dalam pengembangan sumber daya manusia sehingga dapat menopang kualitas pendidikan di lembaga pendidikan islam.

1 Moch Charis Hidayat and Aldo Redho Syam, “Urgensitas Perencanaan Strategis Dan Pengelolaan Sumber Daya Manusia Madrasah Era Revolusi Industri 4.0," AL-ASASIYYA: Journal Of Basic Education 4, no. 1 (2020): 1-13.

2 Ramdanil Mubarok, "Manajemen Pembelajaran Santri Taman Pendidikan AlQur'an (TPA) Darus Sakinah Sangatta Utara," Al-Rabwah 14, no. 02 (2020): 173-88.

${ }^{3}$ Khoirunnisaa', "Manajemen Sumber Daya Manusia (MSDM) Pada Lembaga Pendidikan," An-Nuha : Jurnal Kajian Islam, Pendidikan, Budaya Dan Sosial 5, no. 2 (2018): 209-30.

4 Simamora, Manajemen Sumber Daya Manusia (Yogyakarta: STIE YKPN, 1997), h. 67 . 
Pada zaman Rasulullah SAW. periode madinah merupakan awal mula munculnya lembaga pendidikan Islam seperti masjid, suffah, dan kuttab 5 . Apabila merujuk pada lembaga pendidikan pada periode madinah tersebut maka akan dijumpai lembaga pendidikan yang bergitu banyak dari segi kuantitas pada saat ini berikut dengan jenis lembaga pendidikan Islam yang modern lainnya, namun kuantitas lembaga pendidikan Islam tidak ditopang dengan jaminan kualitas pendidikan. Salah satu faktor yang mendasari semua itu adalah terletak pada kualitas sumber daya manusianya. Diantara faktor lain yaitu: 1) lemahnya manajerial, 2) rendahnya prestasi pendidikan, 3) kurangnya support, 4) tidak memadainya sarana dan prasarana.

Maju tidaknya suatu lembaga pendidikan Islam tergantung pada perencanaan, dan pengelolaan yang baik ${ }^{6}$. Oleh karena itu lembaga pendidikan Islam memerlukan sumber daya manusia yang mumpuni guna terlaksananya proses pendidikan yang efektif supaya tujuan lembaga pendidikan akan mudah untuk dicapai. Lembaga pendidikan merupakan sarana mempersiapkan generasi yang unggul sebagai upaya memajukan bangsa. Namun realitanya lembaga pendidikan Islam masih "ketinggalan" dari lembaga pendidikan umum, hal tersebut terlihat dari data Badan Akreditasi nasional.

Merujuk pada penelitian-penelitian terdahulu yang dilakukan oleh Radit Hijrawan yang meneliti pengebangan manajemen sumber daya manusia berbasis TQM. Hasilnya dalam implementasi TQM perlu perubahan perilaku manajer, dan fokus pada tujuan. Problemnya adalah arogan, tidak fokus, meremehkan potensi bawahan, mengukur kualitas dengan biaya7 .

Selanjutnya Hidayatus Sholihah, hasilnya adalah implementasi manajemen sumber daya manusia dilakukan dengan cara: (1) menyusun perencanaan berdasarkan visi, (2) merekrut tenaga pendidik dan kependidikan dan karyawan yang kompeten (3) menetapkan seleksi dan penempatan berdasarkan kualifikasi akademik dan kompetensinya; (4) melaksanakan pelatihan dan sharing ide dan pengetahuan, studi banding, presentasi internal, evaluasi dan koordinasi; (5) penilaian, administrasi dan supervisi. (6) kompensasi (7) jaminan kesehatan (9) komunikasi ${ }^{8}$.

Demikian juga hasil penelitian dari Fahmiah Akilah mengenai Peran Sumber daya manusia, hasilnya adalah menuntut adanya pemahaman oleh

5 Mahfud Ifendi, "Pendidikan Islam Rasulullah SAW Periode Madinah: Strategi, Materi Dan Lembaga Pendidikan," Al-Rabwah 15, no. 01 (2021): 9-15.

6 Ramdanil Mubarok, "Pelaksanaan Fungsi-Fungsi Manajemen Dalam Peningkatan Mutu Lembaga Pendidikan Islam," Al-Rabwah XIII, no. 1 (2019): 27-44.

7 Radit Hijrawan, "Pengembangan Manajemen Sumber Daya Manusia Berbasis Total Quality Manajemen Di Madrasah Aliyah Nurul Ummah Kotagede Yogyakarta," Al-Fahim: Jurnal Manajemen Pendidikan Islam 1, no. 2 (2019): 109-34.

${ }_{8}$ Hidayatus Sholihah, "Implementasi Manajemen Sumber Daya Manusia Di Man Yogyakarta Iii," Al-Fikri: Jurnal Studi Dan Penelitian Pendidikan Islam 1, no. 1 (2018): 58-71. 
semua tingkatan manajemen, begitu juga dalam manajemen pendidikan. Manusia masih memegang peranan utama dalam keberhasilan suatu asosiasi. Dalam sebuah lembaga pendidikan sumber daya manusia merupakan unsur yang sangat diperlukan karena manusia merupakan unsur pertama dan utama dalam manajemen sebelum aspek lainnya. Oleh karena itu, manajemen sumber daya manusia memiliki peran penting dalam mengelola dan mencapai tujuan organisasi, paling tidak dalam institusi pendidikan. Sumber daya manusia harus diatur dengan tepat sesuai fungsinya agar sumber daya manusia tersebut dapat menjalankan perannya dalam menjalankan tugasnya dan fungsi lembaga yang mereka libatkan. ${ }^{9}$

Berdasarkan fenomena dan paparan studi terdahulu di atas maka diperlukan usaha maksimal dalam mengembangkan sumber daya manusia lembaga pendidikan. Tujuan penulisan artikel ini adalah untuk mengetahui konsep pengembangan manajemen sumber daya manusia, dan proses pengembangan manajemen sumber daya manusia di lembaga pendidikan Islam.

\section{Metode Penelitian}

Paper ini menggunakan jenis penelitian kepustakaan (library research). Penelitian kepustakaan merupakan rangkaian aktivitas mengumpulkan data pustaka dengan membaca, mencatat, dan menginterpretasi menjadi data penelitian ${ }^{10}$. Metode kepustakaan juga merupakan penelitian dengan menjadikan literatur sebagai sumber data utama ${ }^{11}$.

Teknik pengumpulan data dalam paper ini penulis melakukan identifikasi sumber melalui buku-buku, makalah dan artikel, majalah, jurnal online, dan website. Demikian juga hal-hal yang berkaitan dengan pengembangan manajemen sumber daya manusia berupa catatan, buku, majalah dan media online. Tahapan penelitian yang penulis lakukan adalah mengumpulkan bahan penelitian, membaca literatur, membuat catatan kecil, mengolah hasil bacaan menjadi data penelitian.

\section{Hasil Penelitian dan Pembahasan}

\section{Konsep Pengembangan manajemen Sumber Daya Manusia}

\section{Definisi Manajemen}

Manajemen merupakan istilah lain dari mengelola, mengatur, mengarahkan. Asal kata manajemen berasal dari kata "to manage" dimana umumnya diartikan dengan istilah mengatur. Istilah manajemen didefinisikan dalam berbagai perspektif, seperti perspektif pemimpin dan kepemimpinan, perspektif administrasi, perspektif pengelolaan, pengurusan,

9 Fahmiah Akilah, "Peran Manajemen Sumber Daya Manusia Dalam Lembaga Pendidikan," Adaara: Jurnal Manajemen Pendidikan Islam 6, no. 1 (2018): 518-34.

${ }_{10}$ Mestika Zed, Metode Penelitian Kepustakaan (Jakarta: Yayasan Obor Indonesia, 2008), h. 3.

11 Mahmud, Metode Penelitian Pendidikan (Bandung: CV. Pustaka Setia, 2011). 
tata laksana, dan lain sebagainya. Merujuk pada kamus Webster's New Collegiate kata "manage" bermula dari kata "manus" atau juga dari kata "hand", sehingga kata manage dapat bermakna mengurus, membimbing, dan mengawasi untuk mencapai suatu tujuan ${ }^{12}$.

Terminologi manajemen dapat diartikan sebagai sebagai suatu istilah yang dipakai dalam memahami kata "management", dimana pada awal mula penggunaan istilah "management" diartikan sebagai pengelolaan. Berkembangnya ilmu pengetahuan di bidang manajemen kemudian membawa perkembangan tersendiri dalam mendefinisikan manajemen, sehingga definisi manajemen sebagai pengelolaan sudah mulai jarang digunakan. Definisi tentang manajemen semakin berkembang dan menjadi suatu definisi yang lebih spesifik lagi yang dikaitkan dengan fungsifungsinya ${ }^{13}$.

Manajemen juga dapat dikenal dengan istilah efisiensi, dimana tujuan dari penerapan manajemen adalah untuk mengefektifkan dan mengefisienkan waktu dalam mencapai tujuan tertentu. Mengutip dari Peter Drucker dalam artikel Faizal Rizqi Sawaluddin dan Ridwan Rustandi bahwa istilah efisiensi merupakan penekanan pada aspek melaksanakan pekerjaan dengan benar, sementara efektif adalah melaksanakan pekerjaan yang benar ${ }^{14}$.

Istilah manajemen juga didefinisikan oleh George Terry dalam Hadari Nawawi bahwa manajemen merupakan rangkaian aktivitas yang dilakukan untuk mencapai tujuan tertentu yang telah ditetapkan dalam sebuah organisasi dengan bantuan pihak lain ${ }^{15}$. Sementara Mujahid mendefinisikan manajemen sebagai sebuah seni dalam mengatur orang lain dalam menyelesaikan pekerjaan ${ }^{16}$.

Definisi-definisi di atas menunjukkan bahwa dalam pelaksanaan manajemen seorang manajer membutuhkan orang lain dalam menyelesaikan suatu pekerjaan untuk sampai pada tujuan yang telah ditetapkan sebelumnya. Seorang manajer tidak akan mampu bekerja sendiri, namun membutuhkan orang lain sebagai bawahan dengan menciptakan iklim kerja yang kolektif kolegial. Manajer sebagai pemegang tanggung jawab penuh akan mendelegasikan pekerjaan pada bidang tertentu yang sesuai dengan tupoksi untuk mencapai tujuan dengan efektif dan efisien. Jadi, pada intinya

12 Suheli Suheli, "Manajemen Peserta Didik Berbasis Pesantren Dalam Pembentukan Karakter," Jurnal Kependidikan 6, no. 2 (2018): 207-21.

${ }_{13}$ Mujahid, Manajemen Madrasah Mandiri (Jakarta: Puslitbang, 2003), h. 2.

14 Faizal Rizqi Sawaluddin and Ridwan Rustandi, "Manajemen Sumber Daya Manusia Lembaga Pendidikan Islam Di MTs Persis 3 Pameungpeuk," Tadbir: Jurnal Manajemen Dakwah 5, no. 4 (2020): 375-96.

15 Muhammad Priyatna, "Manajemen Pengembangan SDM Pada Lembaga Pendidikan Islam," Edukasi Islami: Jurnal Pendidikan Islam 5, no. 09 (2017): 21.

16 Mujahid, Manajemen Madrasah Mandiri, h. 1. 
manajemen tersebut dilakukan oleh seorang manajer dengan menggunakan segala sumber daya yang ada.

\section{Manajemen Sumber Daya Manusia}

Manajemen sumber daya manusia adalah istilah yang digunakan ilmu manajemen dalam mengelola orang lain dalam sebuah lembaga tertentu. Demikian juga dalam lembaga pendidikan Islam, maka manajemen sumber daya manusia merupakan proses manajemen yang dilakukan oleh seorang pimpinan (kepala sekolah) kepada bawahan (tenaga pendidik dan kependidikan) untuk mencapai tujuan lembaga pendidikan.

George Terry dalam Restanti mengatakan bahwa manajemen sumber daya manusia merupakan praktek kebijakan yang dilakukan seorang manajer dalam menjalankan sumber daya manusia melalui proses penyaringan, perekrutan, pelatihan, penilaian, dan pengimbalan ${ }^{17}$.

Sondang P. Siagian mendefinisikan sumber daya manusia sebagaimana dikutip Sandi dkk. bahwa manajemen sumber daya manusia merupakan unsur penting dalam lembaga pendidikan ${ }^{18}$. Sebuah lembaga pendidikan akan berhasil dalam mencapai tujuan apabila lembaga tersebut mampu menghadapi berbagai tantangan dan rintangan, baik yang bersifat internal maupun eksternal. Keberhasilan lembaga tersebut ditentukan oleh kompetensi manajer dalam mengembangkan dan mengelola sumber daya manusia yang ada.

Manajemen sumber daya manusia jika dibawa pada proses pembelajaran di lembaga pendidikan maka sangat diperlukan untuk tercapainya pembelajaran yang efektif. Guru sebagai sumber daya manusia menjadi kunci keberhasilan proses pembelajaran di lembaga pendidikan sehingga perlu untuk dibimbing, diarahkan, sesuai dengan tujuan lembaga pendidikan yang telah ditentukan sebelumnya. Peran guru sampai hari ini tidak akan mungkin dapat digantikan oleh mesin sekalipun karena tugas guru terkait dengan pembinaan moral dan mental ${ }^{19}$.

Guru dituntut untuk profesional dalam menjalankan tugasnya di lembaga pendidikan. Guru harus komitmen dengan profesinya sebagai seorang pendidik, pembimbing, pengarah, dan pengajar di lembaga pendidikan. Guru dikatakan sebagai guru profesional apabila sikap dedikatif terhadap tugas, komitmen dengan mutu, selalu berusaha mengupgrade

17 Anisa Sri Restanti, "Sumber Daya Manusia Dalam Pengembangan Perpustakaan: Studi Pemikiran Lasa Hs.," UNILIB: Jurnal Perpustakaan 6, no. 1 (2019): 41-52.

18 Qalka Sandi, Ahmad Syukri, and Kasful Anwar US, "Manajemen Sumber Daya Manusia Dalam Meningkatkan Keunggulan Kompetitif," Al Ghazali 2, no. 2 (2019): 63-84.

${ }^{19}$ Khusnul Wardan, "Pembinaan Mutu Guru Melalui Program Sertifikasi Dan Penilaian Kinerja Guru Pada Dinas Pendidikan Kabupaten Kutai Timur," Al-Rabwah 13, no. 02 (2019): 84-102. 
kompetensi melekat dalam dirinya ${ }^{20}$. Guru sebagai sumber daya manusia di lembaga pendidikan memang mempunyai tugas yang tidak mudah. Disamping tuntutan profesionalisme guru juga dituntut untuk mengikuti perkembangan zaman termasuk perkembangan teknologi dan informasi.

Seorang guru bukan hanya sebagai pengajar di lembaga pendidikan, namun ia juga harus menanamkan kesadaran dalam dirinya sebagai orang yang digugu dan ditiru. Seorang guru tidak hanya mengajar ilmu pengetahuan, namun ia juga dituntut membimbing karakter peserta didik guna menyiapkan generasi masa depan yang lebih baik sebagai dengan berbagai tantangannya.

Merujuk pada argumen medley sebagaimana dikutip Muhaimin ${ }^{21}$, Suriadi dan Mursidin ${ }^{22}$, Andi Prastowo ${ }^{23}$, Mukhlis ${ }^{24}$, bahwa dalam mengembangakan guru sebagai sumber daya manusia mempunyai beberapa asumsi: 1) Guru tergantung pada kepribadiannya, 2) Guru tergantung pada metode pengajarannya, 3) Guru tergantung pada hubungannya dengan siswa, 4) Guru sebagai orang yang berpengetahuan dan wawasan yang luas. Kesimpulannya adalah sumber daya manusia memegang peranan penting yang berkelanjutan dan terpadu dalam membuat terobosan-terobosan baru dalam sebuah lembaga pendidikan guna tercapainya tujuan yang diinginkan.

\section{Teori Manajemen Sumber Daya Manusia}

Teori tentang manajemen sumber daya manusia tentunya tidak terlepas daripada manusia itu sendiri. Manusia merupakan aspek pokok dalam manajemen sumber daya manusia. Eksistensi manajemen sumber daya manusia dalam sebuah lembaga pendidikan ditentukan oleh manusia, karena manusia merupakan sebaik-baik ciptaan (ahsani taqwim), hal tersebut jelas tertulis di dalam Al-Qur'an surat At-Tin:

20 Tri Andiyanto, "Peran Pendidik Agama Islam Terhadap Pembentukan Kepribadian Anak Usia Dini," IJIGAEd: Indonesian Journal of Islamic Golden Age Education 1, no. 2 (2021): 21-30.

21 Muhaimin, Wacana Pengembangan Pendidikan Islam (Yogyakarta: Pustaka Pelajar, 2003), h. 210.

22 Suriadi Suriadi and Mursidin Mursidin, "Teori-Teori Pengembangan Pendidik: Sebuah Tinjauan Ilmu Pendidikan Islam," Jurnal Al-Qiyam 1, no. 2 (2020): $51-62$

23 Andi Prastowo, "Kapasitas Guru Profesional Di Pendidikan Dasar Islam," LITERASI (Jurnal Ilmu Pendidikan) 4, no. 2 (2016): 233-54.

${ }_{24}$ Mukhlis Fr, "Kompetensi Guru Madrasah Ibtidaiyah Dalam Pembelajaran Sains Berbasis Pendidikan Karakter," Jurnal Studi Islam Al-'Ulum 1, no. 14 (2019): 11 26. 


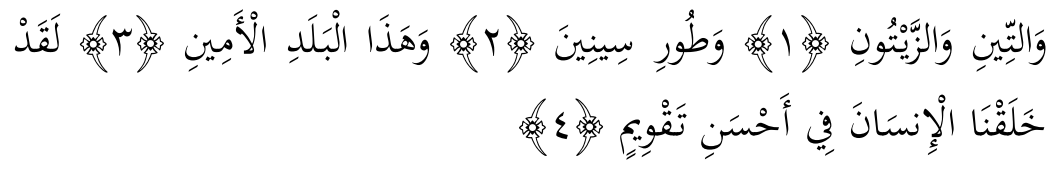

Artinya: (1) Demi (buah) Tin dan (buah) Zaitun, 2. dan demi bukit Sinai, (3) dan demi kota (Mekah) ini yang aman, (4) sesungguhnya Kami telah menciptakan manusia dalam bentuk yang sebaik-baiknya.

Manusia diciptakan dalam bentuk sebaik-baik ciptaan yang dilengkapi dengan akal untuk berpikir. Kemampuan berpikir manusia inilah yang menjadikannya mampu untuk membimbing, mengelola, dan mengembangkan sebuah lembaga pendidikan.

Teori-teori tentang sumber daya manusia dalam sebuah organisasi atau lembaga pendidikan banyak macamnya. Dan implementasi dari teori tersebut juga bermacam-macam bentuknya tergantung tujuan yang ingin dicapai oleh lembaga pendidikan. Apapun bentuk implementasi dan ragam teori yang digunakan sesungguhnya semua itu bermuara dari sifat dasar seorang manusia.

Mula-mula manusia dikategorikan sebagai alat karena pada hakikatnya manusia adalah seorang pekerja yang dapat menghasilkan sesuatu. Pada masa awal inilah manusia dipandang sama dengan alat yang membutuhkan pemeliharaan, perawatan, dan pengendalian. Proses tersebut terus berlangsung sampai pada masa kini dengan kecanggihan teknologi informasi. Menurut Eris Yustiono bahwa sebenarnya manusia bukanlah kunci pertama keberhasilan apapun, termasuk sumber daya lainnya ${ }^{25}$.

Pada perkembangan selanjutnya, pentingnya manajemen sumber daya manusia mulai disadari oleh para manajer maupun lembaga pendidikan sehingga tidak lagi menganggap manusia sebagai sebuah alat yang dapat menentukan sebuah hasil. Karenanya pengimplementasian manajemen yang berorientasi pada kepentingan berbagai macam pihak terkait menempatkan manusia pada posisi sentral manajemen ${ }^{26}$. Maka sumber daya manusia perlu dikelola dengan maksimal untuk menghasilkan hasil yang berkualitas. Maka manusia menjadi unsur dasar utama dalam manajemen. Pada intinya semua fungsi tersebut merupakan unsur yang saling berkaitan guna meningkatkan produktivitas.

Jika dikaitkan pada ranah lembaga pendidikan maka fungsi manajerial tersebut merupakan fungsi manajemen pendidikan yang meliputi manajemen pendidikan. Selanjutnya pada fungsi operasional di lembaga pendidikan merupakan pengelolaan pada proses pelaksanaan pembelajaran di lembaga pendidikan. Islam."

25 Priyatna, "Manajemen Pengembangan SDM Pada Lembaga Pendidikan

26 Yohanes Arianto Budi Nugroho, Pelatihan Dan Pengembangan SDM: Teori Dan Aplikasi (Jakarta: Penerbit Unika Atma Jaya, 2019), h. 29. 
Lain lagi dengan Werner dan De Simon, yang membagi fungsi manajemen sumber daya manusia menjadi lebih umum bahwa fungsi manajemen sumber daya manusia terdiri dari fungsi utama dan fungsi pendukung. ${ }^{27}$ Dimana fungsi utama manajemen sumber daya manusia terdiri dari perencanaan, kesempatan dalam kesetaraan, pengadaan karyawan, rekrutmen dan seleksi, kompensasi dan manfaat, hubungan kekaryawanan, kesehatan, keselamatan dan keamanan kerja, pengembangan sumber daya manusia. Adapun faktor pendukungnya adalah desain pekerjaan, sistem penilaian kinerja manajemen dan karyawan, penelitian dan sistem informasi.

Semua fungsi yang disebutkan di atas menunjukkan bahwa adanya keterkaitan pada fungsi-fungsi tersebut dimana satu fungsi dengan bagian bagiannya saling melengkapi dengan fungsi yang lain. Dalam lembaga pendidikan juga demikian, implementasi manajemen sumber daya manusia di lembaga pendidikan maka berkaitan dengan tenaga pendidik, dan tenaga kependidikan. Dimana dalam hal pengelolaan tenaga pendidik dan kependidikan di lembaga pendidikan membutuhkan perencanaan, kesempatan dalam kesetaraan, pengadaan karyawan, rekrutmen dan seleksi, kompensasi dan manfaat, hubungan kekaryawanan, kesehatan, keselamatan dan keamanan kerja, dan pengembangan sumber daya manusia.

Pada fungsi pendukung juga demikian, di lembaga pendidikan membutuhkan desain pekerjaan, sistem penilaian kinerja manajemen, tenaga pendidik dan tenaga kependidikan, serta penelitian dan sistem informasi.

\section{Proses Pengembangan Manajemen Sumber Daya Manusia di Lembaga Pendidikan Islam}

Pengembangan sumber daya manusia membutuh proses yang panjang guna mendapatkan hasil yang optimal. Secara sederhana pengembangan sumber daya manusia berarti adanya proses perencanaan, pengorganisasian, pengarahan, dan pengawasan sebagaimana fungsi manajemen pada umumnya.

Pengembangan sumber daya manusia juga dapat dilihat dari adanya proses pengadaan atau perekrutan manusianya, ada kompensasi yang diberikan, adanya pengintegrasian antara unsur satu dengan unsur lainnya, serta adanya pemeliharaan guna tercapainya tujuan lembaga pendidikan. Karena pada dasarnya kembali ditegaskan bahwa manusia merupakan sumber daya yang tidak terbatas dengan kesempurnaan penciptaan dan akal yang dimilikinya.

Pengembangan sumber daya manusia di lembaga pendidikan dalam hal ini merupakan pendidik dan tenaga kependidikan merupakan adanya proses pembelajaran dan pelatihan guna meningkatkan kinerja serta kompetensinya pada masa sekarang dan merupakan persiapan untuk

27 Jon M. Werner dan Randy L. De Simone, Human Resource Development (Mason USA: Cengange Learning, 2012), h. 11. 
peningkatan kompetensi peran dan tanggung jawab dimasa yang akan datang 28 .

Proses pengembangan sumber daya manusia di lembaga pendidikan harus berdasarkan analisis kebutuhan dan perencanaan yang matang sehingga dapat mendukung proses ketercapaian tujuan lembaga pendidikan. Proses yang baik dan cermat akan menghasilkan sumber daya manusia yaitu tenaga pendidik dan pendidikan yang berkualitas.

Sumber daya manusia yang berkualitas dalam artikel Mona Novita antara lain apabila bekerja tidak sembrono, hasil kerjanya bernilai, bekerja secara optimal, komitmen terhadap pekerjaan, bekerja dengan memperhatikan kualitas serta mutunya, menggunakan waktu bekerja dengan efektif dan efisien ${ }^{29}$.

Dengan demikian seseorang dikatakan sebagai tenaga pendidik dan kependidikan berkualitas di lembaga pendidikan apabila dalam bekerja mempunyai pertimbangan dan perhitungan yang matang dalam setiap tindakannya. Tidak tergesa-gesa dalam setiap pengambilan keputusan. Dalam bekerja memperhatikan dan menetapkan nilai-nilai dalam perencanaannya. Dalam pelaksanaannya juga demikian, sumber daya manusia yang berkualitas tidak akan bekerja dan mengajar asal-asalan. Ia akan mengedepankan kualitas dan mutu pekerjaannya serta akan menggunakan waktu dengan efektif dan efisien. Seorang tenaga pendidik akan mengajar sesuai dengan perangkat pembelajaran yang telah disusun. Seorang tenaga kependidikan akan memberikan pelayanan terbaik di lingkungan lembaga pendidikannya.

Demikian pula dalam lembaga pendidikan Islam, sumber daya manusia yang berkualitas apabila dilihat dari perspektif Islam sebagaimana artikel yang ditulis Djaelany Haluty bahwa pengelolaan sumber daya manusia di lembaga pendidikan Islam harus mengacu pada apa yang telah dicontohkan oleh Nabi Muhammad SAW. yang berlandaskan pada konsep Islam tentang penciptaan manusia yaitu konsep tujuan manusia diciptakan untuk beribadah kepada Allah SWT., dan konsep manusia diciptakan di muka bumi sebagai khalifah ${ }^{30}$.

Lebih lanjut jika dilihat lebih spesifik lagi dalam perspektif Al-Qur'an maka manusia yang berkualitas ditopang dengan kualitas keimanan, kualitas

28 Sakban Sakban, Ifnaldi Nurmal, and Rifanto Bin Ridwan, "Manajemen Sumber Daya Manusia," Alignment: Journal of Administration and Educational Management 2, no. 1 (2019): 93-104.

29 Mona Novita, “Sumber Daya Manusia Yang Berkualitas Sebagai Harta Yang Berharga Dalam Sebuah Lembaga Pendidikan Islam," Nur El-Islam 4, no. 1 (2017): 4064 .

30 Djaelany Haluty, "Islam Dan Manajemen Sumber Daya Manusia Yang Berkualitas," Irfani 10, no. 1 (2014): 29299. 
ilmu pengetahuan, kualitas perbuatan baik, kualitas kehidupan sosialnya, dan kualitas kerjanya ${ }^{31}$.

Dengan demikian perlu pengembangan sumber daya manusia di lembaga pendidikan Islam guna mencapai tujuan yang telah ditentukan. Sumber daya manusia yang berkualitas dapat dikembangkan dan diupayakan dengan berbagai macam cara, diantaranya menurut Nasir Usman antara lain : 1) dapat dikembangkan dengan pendidikan, 2) dapat dikembangkan dengan pelatihan, 3) dapat dikembangkan secara mandiri ${ }^{32}$.

Proses pengembangan sumber daya manusia dapat dikembangkan melalui proses pendidikan. Pada dasarnya proses pengembangan sumber daya manusia itu telah terjadi sejak manusia itu mengenyam pendidikan pada tingkat dasar sampai pada pendidikan tinggi. Kemudian selanjutnya dikembangkan melalui pelatihan dapat dilakukan setelah manusia tersebut berada di lingkungan kerja. Ketika tenaga pendidik di lembaga pendidikan akan dikembangkan kompetensinya maka seorang manajer harus mengupayakan pelatihan-pelatihan, seminar-seminar, workshop-workshop, dan bahkan studi banding. Apabila pendidikan dan pelatihan sebagai upaya pengembangan sumber daya manusia telah dilakukan maka tahap selanjutnya adalah pengembangan diri sendiri manusianya.

Kenyataannya dalam pengembagan diri manusia sendiri akan mengalami hambatan dan rintangan yang tidak sedikit, termasuk dari segi sarana dan prasaranannya ${ }^{33}$. Banyak faktor yang menjadi penghambat pengembangan diri sumber daya manusia secara mandiri, sehingga manajer perlu mencari solusi dari permasalahan tersebut. Manajer perlu mengapresiasi setiap upaya pengembangan mandiri yang dilakukan oleh tenaga pendidik dan kependidikan dengan memberikan penghargaan dan reward. Hal tersebut merupakan bentuk apresiasi manajer dan lembaga pendidikan serta akan menjadi rangsangan bagi sumber daya lain untuk ikut berpacu dalam pengembangan kompetensi dirinya.

Hasil penelitian Desi dkk. mengenai problem pengembangan sumber daya manusia menghasilkan 1) adanya tugas tambahan di lembaga pendidikan, 2) kurangnya komunikasi dan koordinasi, 3) pendelegasian tugas, 4) pemahaman sumber daya manusia terhadap visi dan misi lembaga pendidikan, 5) kurangnya pengawasan, 6) penguasaan teknologi informasi dan komunikasi (TIK) ${ }^{34}$. Problem yang dihasilkan dalam penelitian diatas

31 Muhamad Akip, "Sumber Daya Manusia Yang Berkualitas Dalam Al Qur'an," El-Ghiroh: Jurnal Studi Keislaman 17, no. 02 (2019): 45-60.

32 Nasir Usman, Manajemen Peningkatan Mutu Kinerja Guru, Konsep, Teori, Dan Model (Bandung: Citapustaka Media Perintis, 2012), h. 17.

33 Muhammad Ibnu Faruk Fauzi, "Manajemen Sarana Dan Prasarana Pendidikan," Al-Rabwah 14, no. 02 (2020): 90-115.

34 Desi Eri Kusumaningrum, Raden Bambang Sumarsono, and Imam Gunawan, “Problematika Pemberdayaan Dan Pengembangan Sumber Daya Manusia Di Sekolah 
merupakan keterwakilan lembaga pendidikan Islam pada umumnya karena disatu sisi lembaga pendidikan Islam merupakan lembaga yang berdiri secara mandiri yang sebagian besar akomodasi dan operasionalnya berasal dari swadaya masyarakat.

Oleh karena itu pengembangan sumber daya manusia di lembaga pendidikan Islam harus diawali dengan perencanaan yang matang. Proses pegembangan manajemen sumber daya manusia lembaga pendidikan Islam harus mampu merencanakan peluang dan tantangan, mampu memprediksi dan menganalisa kemungkinan-kemungkinan di masa yang akan datang. Dalam perekrutan sumber daya manusia juga harus memperhatikan kebutuhan jangka panjang sehingga sumber daya manusia yang ada dapat dioptimalkan jangka panjang.

Menurut Robert L. Mathius dan John H. Jackson yang diterjemahkan oleh Diana mengatakan bahwa pengembangan sumber daya manusia dilakukan dengan dua cara, yaitu menetapkan rencana sumber daya manusia, dan menetapkan rencana pengembangan sumber daya manusia ${ }^{35}$.

Jadi ada perencanaan sumber daya manusianya dan ada perencanaan pengembangannya dimana dalam proses perencanaan keduanya harus memperhatikan kebutuhan lembaga pendidikan. Kemudian terakhir melakukan evaluasi tingkat keberhasilan proses pengembangan tersebut disesuaikan dengan kebutuhan maupun perubahan iklim, kebijakan, dan masa suatu lembaga pendidikan.

Lembaga pendidikan membutuhkan strategi-strategi yang efektif guna terlaksananya pengembangan sumber daya manusia (tenaga pendidik), sebagaimana menurut Nasir Usman sebagai berikut: 1) membuat desain perencanaan 2) adanya program pengembangan tenaga pendidik, 3) melaksanakan program yang telah direncanakan 4) melakukan evaluasi proses $^{36}$.

Terdapat empat fase dalam proses pengembangan sumber daya manusia, diantaranya:

1. Fase Diagnostik

Fase ini merupakan upaya mencari tahu akan kebutuhan dalam pengembangan sumber daya manusia yang berkaitan dengan kebutuhan individu, kelompok, dan kebutuhan lembaga pendidikan. Rencana yang disusun harus mampu menjawab segala persoalan dan tantangan lembaga pendidikan.

2. Fase Desain

Menengah Pertama Berbasis Pesantren," Ilmu Pendidikan: Jurnal Kajian Teori Dan Praktik Kependidikan 2, no. 2 (2017): 139-50.

35 Diana Angelica, Manajemen Sumber Daya Manusia (Jakarta: Salemba Empat, 2004), h. 352.

36 Usman, Manajemen Peningkatan Mutu Kinerja Guru, Konsep, Teori, Dan Model, h. 110. 
Pada fase kedua ini merupakan upaya yang dilakukan dalam merancang bagaimana desain pengembangan manajemen sumber daya manusia. Setelah mengetahui diagnosa pada fase pertama kemudian mendesain perencanaan berdasarkan 1) masalah lembaga pendidikan, 2) kebutuhan program lembaga pendidikan, 3) partisipasi stakeholder, 4) merencanakan sumber daya manusia cadangan, 5) kalender pendidikan, 6) kebutuhan individu, 7) kebutuhan kelompok, 8) sumber daya manusianya, 9) waktu, 10) prosedur, 11) evaluasi.

3. Fase Implementasi

Pada fase ketiga adalah melaksanakan dan menjalankan desain yang sudah direncanakan dalam tindakan nyata. Pelaksanaannya harus sesuai dengan urutan fase-fase di atas. Dalam fase implementasi ini juga diperlukan dukungan dari berbagai pihak dan melakukan koordinasi guna mewujudkan sumber daya manusia yang profesional.

4. Fase Evaluasi

Pada fase ini merupakan fase terakhir dalam pengembagan manajemen sumber daya manusia. Pada fase evaluasi ini harus melihat kinerja dan metode yang digunakan serta mengevaluasi setiap fase dalam proses pengembangan manajemen sumber daya manusia.

Dari keempat fase yang telah dijelaskan di atas maka manajer sebagai pemegang kebijakan harus menentukan posisi pengembangan manajemen sumber daya manusianya. Dengan menjalankan fase-fase pengembangan tersebut maka akan dapat diperoleh sumber daya manusia yang berkualitas, terampil, dan cakap dalam menyelesaikan tugas dan tanggung jawab.

Tahapan proses pengembangan manajemen sumber daya manusia sebagaimana diadaptasi dari Werther dan Davis dapat dilakukan dengan: 1) melakukan analisis kebutuhan dimana analisis kebutuhan dapat dilakukan dengan menganalisa kebutuhan lembaga pendidikannya, menganalisa tugas dan pekerjaanya, menganalisa sumber daya manusianya. 2) Menentukan tujuan yang konkrit supaya memudahkan dalam merencanakan, mengkoordinasikan, melaksanakan, dan melakukan evaluasi ${ }^{37}$.

37 D Rajan, "Training Needs Analysis: A Study of Managers," Training $\mathcal{E}$ Development Journal 9, no. 2 (2018): 144-54. 


\section{Kesimpulan}

Berdasarkan analisa yang dilakukan menghasilkan konsep manajemen sumber daya manusia sebagai proses mengelola orang lain dilakukan oleh seorang pimpinan (kepala sekolah) kepada bawahan (tenaga pendidik dan kependidikan) untuk mencapai tujuan lembaga pendidikan. Manusia merupakan aspek pokok dalam manajemen sumber daya manusia. Eksistensi manajemen sumber daya manusia dalam sebuah lembaga pendidikan ditentukan oleh manusia, karena manusia merupakan sebaik-baik ciptaan. Adapun proses pengembangan manajemen sumber daya manusia di lembaga pendidikan Islam pada umumnya merupakan implementasi dari fungsifungsi manajemen yaitu perencanaan, pengorganisasian, pelaksanaan, dan pengawasan. Maka proses pengembangan sumber daya manusia dilakukan, pertama: dengan melakukan diagnosa kebutuhan, kedua: melakukan desain masalah, desain program, desain partisipasi, desain kalender pendidikan, desain kebutuhan individu, desain kebutuhan kelompok, desain waktu, prosedur, dan evaluasi, ketiga: proses pelaksanaan, dan terakhir melaksanakan evaluasi.

\section{Daftar Pustaka}

Akilah, Fahmiah. "Peran Manajemen Sumber Daya Manusia Dalam Lembaga Pendidikan." Adaara: Jurnal Manajemen Pendidikan Islam 6, no. 1 (2018).

Akip, Muhamad. "Sumber Daya Manusia Yang Berkualitas Dalam Al Qur'an." El-Ghiroh: Jurnal Studi Keislaman 17, no. 02 (2019).

Andiyanto, Tri. "Peran Pendidik Agama Islam Terhadap Pembentukan Kepribadian Anak Usia Dini." IJIGAEd: Indonesian Journal of Islamic Golden Age Education 1, no. 2 (2021).

Angelica, Diana. Manajemen Sumber Daya Manusia. Jakarta: Salemba Empat, 2004.

Fauzi, Muhammad Ibnu Faruk. "Manajemen Sarana Dan Prasarana Pendidikan." Al-Rabwah 14, no. 02 (2020).

Fr, Mukhlis. "Kompetensi Guru Madrasah Ibtidaiyah Dalam Pembelajaran Sains Berbasis Pendidikan Karakter." Jurnal Studi Islam Al-'Ulum 1, no. 14 (2019).

Haluty, Djaelany. "Islam Dan Manajemen Sumber Daya Manusia Yang Berkualitas." Irfani 10, no. 1 (2014).

Hidayat, Moch Charis, and Aldo Redho Syam. "Urgensitas Perencanaan Strategis Dan Pengelolaan Sumber Daya Manusia Madrasah Era Revolusi Industri 4.0." AL-ASASIYYA: Journal Of Basic Education 4, no. 1 (2020).

Hijrawan, Radit. "Pengembangan Manajemen Sumber Daya Manusia Berbasis Total Quality Manajemen Di Madrasah Aliyah Nurul Ummah Kotagede Yogyakarta." Al-Fahim: Jurnal Manajemen Pendidikan Islam 1, no. 2 (2019).

Ifendi, Mahfud. "Pendidikan Islam Rasulullah SAW Periode Madinah: 
Strategi, Materi Dan Lembaga Pendidikan." Al-Rabwah 15, no. 01 (2021). Jon M. Werner dan Randy L. De Simone. Human Resource Development. Mason

USA: Cengange Learning, 2012.

Khoirunnisaa'. "Manajemen Sumber Daya Manusia (MSDM) Pada Lembaga

Pendidikan." An-Nuha: Jurnal Kajian Islam, Pendidikan, Budaya Dan Sosial

5, no. 2 (2018).

Kusumaningrum, Desi Eri, Raden Bambang Sumarsono, and Imam Gunawan. "Problematika Pemberdayaan Dan Pengembangan Sumber Daya Manusia Di Sekolah Menengah Pertama Berbasis Pesantren." Ilmu Pendidikan: Jurnal Kajian Teori Dan Praktik Kependidikan 2, no. 2 (2017).

Mahmud. Metode Penelitian Pendidikan. Bandung: CV. Pustaka Setia, 2011.

Mubarok, Ramdanil. "Manajemen Pembelajaran Santri Taman Pendidikan

Al-Qur'an (TPA) Darus Sakinah Sangatta Utara." Al-Rabwah 14, no. 02 (2020).

- - - . "Pelaksanaan Fungsi-Fungsi Manajemen Dalam Peningkatan Mutu Lembaga Pendidikan Islam." Al-Rabwah XIII, no. 1 (2019).

Muhaimin. Wacana Pengembangan Pendidikan Islam. Yogyakarta: Pustaka Pelajar, 2003.

Mujahid. Manajemen Madrasah Mandiri. Jakarta: Puslitbang, 2003.

Novita, Mona. "Sumber Daya Manusia Yang Berkualitas Sebagai Harta Yang

Berharga Dalam Sebuah Lembaga Pendidikan Islam." Nur El-Islam 4, no. 1 (2017).

Nugroho, Yohanes Arianto Budi. Pelatihan Dan Pengembangan SDM: Teori Dan Aplikasi. Jakarta: Penerbit Unika Atma Jaya, 2019.

Prastowo, Andi. "Kapasitas Guru Profesional Di Pendidikan Dasar Islam." LITERASI (Jurnal Ilmu Pendidikan) 4, no. 2 (2016).

Priyatna, Muhammad. "Manajemen Pengembangan SDM Pada Lembaga Pendidikan Islam." Edukasi Islami: Jurnal Pendidikan Islam 5, no. 09 (2017).

Rajan, D. "Training Needs Analysis: A Study of Managers." Training $\mathcal{E}$ Development Journal 9, no. 2 (2018).

Restanti, Anisa Sri. "Sumber Daya Manusia Dalam Pengembangan Perpustakaan: Studi Pemikiran Lasa Hs." UNILIB: Jurnal Perpustakaan 6, no. 1 (2019).

Sakban, Sakban, Ifnaldi Nurmal, and Rifanto Bin Ridwan. "Manajemen Sumber Daya Manusia." Alignment: Journal of Administration and Educational Management 2, no. 1 (2019).

Sandi, Qalka, Ahmad Syukri, and Kasful Anwar US. "Manajemen Sumber Daya Manusia Dalam Meningkatkan Keunggulan Kompetitif." Al Ghazali 2, no. 2 (2019).

Sawaluddin, Faizal Rizqi, and Ridwan Rustandi. "Manajemen Sumber Daya Manusia Lembaga Pendidikan Islam Di MTs Persis 3 Pameungpeuk." Tadbir: Jurnal Manajemen Dakwah 5, no. 4 (2020).

Sholihah, Hidayatus. “Implementasi Manajemen Sumber Daya Manusia Di Man Yogyakarta Iii." Al-Fikri: Jurnal Studi Dan Penelitian Pendidikan Islam 
1, no. 1 (2018).

Simamora. Manajemen Sumber Daya Manusia. Yogyakarta: STIE YKPN, 1997.

Suheli, Suheli. "Manajemen Peserta Didik Berbasis Pesantren Dalam Pembentukan Karakter. Jurnal Kependidikan 6, no. 2 (2018).

Suriadi, Suriadi, and Mursidin Mursidin. "Teori-Teori Pengembangan Pendidik: Sebuah Tinjauan Ilmu Pendidikan Islam." Jurnal Al-Qiyam 1, no. 2 (2020).

Usman, Nasir. Manajemen Peningkatan Mutu Kinerja Guru, Konsep, Teori, Dan Model. Bandung: Citapustaka Media Perintis, 2012.

Wardan, Khusnul. Pembinaan Mutu Guru Melalui Program Sertifikasi Dan Penilaian Kinerja Guru Pada Dinas Pendidikan Kabupaten Kutai Timur. Al-Rabwah 13, no. 02 (2019).

Zed, Mestika. Metode Penelitian Kepustakaan. Jakarta: Yayasan Obor Indonesia, 2008. 